\title{
ESPIONAGE IN SALT FILM: A STUDY OF POPULAR LITERATURE
}

\author{
Juli Setyoningrum and Lusia Kristiasih Dwi Purnomosasi \\ Department of English Teaching \\ Faculty of Letters and Arts Education IKIP PGRI Madiun \\ julisetyo86@gmail.com lusiakdp@gmail.com
}

\begin{abstract}
Film is one of the popular literary product that are produced to entertain. Film is the object material for this research study. This research analyzes about espionage in Salt film. It analyzes focus in Espionage that happen in the world. Espionage practices in Salt film are related closely to the espionage in the world. The aim of this research is to analyze why is the espionage still exist up to $21^{\text {st }}$ century. A study of popular literature is chosen by the researcher in order to analyze the research problems. The results of the research are to show that United States is the winner of Cold War with its espionage activity. Salt is an espionage film that contains the high intelligence, secret cover, spy cases, and war of ideology. The development of espionage films where Hollywood always makes United States as the winner is the evident that espionage film is populer. The popularity of espionage films is influenced by the espionage practices in the real world. Espionage in the $21^{\text {st }}$ century still occurs in some countries with difference motives. The purposes of the espionage activities are to show the superiority, power and existence of some countries especially United States as an international police in the world.
\end{abstract}

Key terms: Popular Literature, Espionage, Hollywood

\section{INTRODUCTION}

Everything that is trend in the society is influenced by the popular culture. Popular culture is the mass culture (Strinati, 1995: 1). It is produced by the mass production industry and marketed for profit to a mass public of customers. The product of the popular culture in the literary work is known as the popular literature that accepted and desired by the society and become popular (Adi, 2011: 24). The purposes of the popular literature are to supply the requirement of the modern society that always need entertainment, knowledge and for the commercial business. Film is an example of popular literature.

The researcher chooses Salt film as the object material because this film has the challenging theme. Espionage is the theme of this film where there is still unanswered question, "Who is Salt?" Make this film so interesting. Next, the general action espionage films which are always starred by men that show their masculinity and good action capability, but Salt is starred with Angelina Jolie, who acts a lot of dangerous actions 
mostly by herself without the stunt actor. So, the researcher wants to analyze how she works undercover in Salt film.

Salt is the 2010 American action thriller espionage film that is inspired from the setting of Cold War era between United States and Soviet Union. Competition between the superpowers and their allies physically has finished but the espionage still happen until now. The Salt film is produced and distributed by the Columbia Picture, directed by Philip Noyce, written by Kurt Wimmer, and starred by Angelina Jolie, Liev Schreiber, Daniel Olbrychski, August Diehl, and Chiwetel Ejiofor. This film is the successful film in 2010, with United States and Canada boxoffice receipts $\$ 118,311,368$, in other countries receipts $\$ 175,191,986$ and for a worldwide total of $\$ 293,503,354$ (Box Office Mojo, 2015). Getting awards and making nominees show that this film is popular.

The salient motifs of the Cold War are the story of espionage. Espionage is the activity of operating with the greatest secrecy, get the rival's crucial information with the secret operation. Codes, cryptology, and secret writing are the ways to send the information and the crucial messages are not understood by the enemy (Lerner and Lerner, 2004: 22). The espionage agency of United States is called the Central Intelligence Agency (CIA) and Komitet Gosudarstvennoy Bezopasnosti (KGB) is Soviet Union's espionage agency.
There are many cases of the espionage which done by the CIA and KGB to get the enemy's information since the Cold War period until the $21^{\text {st }}$ century. The researcher wonders to know whether espionage still exists after Cold War era.

Concerning the assumptions above, the researcher will investigate the phenomenon based on the assumption that Cold War between United States and Soviet Union is never end. By espionage films, Hollywood wants to show the power of United States. So, the researcher conducts a research under the title "Espionage in Salt Film: A Study of Popular Literature.

\section{RESEARCH METHOD}

A qualitative design is applied for this research. The researcher analyzes the espionage that consideration with qualitative phenomena. In qualitative research to begin the study the researcher gets data of the primary data and secondary data (Ary et al., 2010: 443). In this research, the primary data is the Salt film. The secondary sources that have done by the researcher are from books, articles, webs, and other espionage films that related with the analysis of the espionage as study of popular literature. The researcher uses documentation as data collection technique to analyze the espionage in Salt film. In this research, the researcher analyzes the data using content analysis. The reseacher analyzes 
the visual material as the documents of popular culture that is film of Salt.

\section{RESULT}

The Cold War is more emphasized on the war of ideology. United States and Soviet Union compete to expand their ideologies around the world. The film of Salt presents the ideology war between United States and North Korea. The ideology of United States is an imperial liberalism, so Evelyn Salt is American imperialist. Evelyn Salt as the American who is arrested as a spy by the North Korea. United States and North Korea have different ideology where United States is liberalis and North Korea as allies country os Soviet Union is communist. United States and North Korea have bad relationship and suspicious each other since the Cold War era until now. North Korea and United States involve in the Korean War at 1950s. They are still hostile since the conflict end only in an armistice but not in peace treaty.

The other ideology war in Salt film is when Soviet Union doctrines its ideology to the citizen with the purpose to destroy the enemy's ideology. When Orlov tells a great secret about Soviet Union's mission to Evelyn Salt. A baby from the Chenkov's family who is guessed have died of fever, but the fact that she is still alive. The child is kidnapped by the master spy of Soviet. The child and other children are brainwashed by doctrine antiUnited States and loyal to their country. They are doctrined about the ideology of Soviet Union since they are childhood up to adulthood. They are sent to United States and adopted by the American family. They become American with the great mission as Soviet Union's agents. They are expected to work in the important state institutions in United States, so they get a lot of crucial data and information about the country. It takes up to 30 years to carry out the mission, but they are able to implant the idealism and make the mission happen. What happens with Evelyn Salt does not match with what is expected. She is a Soviet secret agent who works undercover for United States. During her time as a member of the CIA, Evelyn Salt promises to be faithful to her duties as a member of the CIA and United States. It is contrary to the ideology that have been doctrined to her by Soviet Union.

There are same cases of espionase activities that implied in Salt film and some espionage films. Those are the recruitment of the new espionage agent, the placement of espionage agent, the secret cover of espionage agen, the women agent in espionage, and the special devices that used by espionage agent to support her or his mission.

\section{DISCUSSION}

Entering the $21^{\text {st }}$ century the era of the Cold War comes to a new phase. This is caused by the rise of Soviet Union and new countries that will be the next competitors to 
United States. Although the Cold War is ending, but there are a lot of legacies which still continues today. One of them is a war of espionage between the Western countries that are led by United States against the allied countries of Soviet Union and the countries that will be the next competitors to United States. Espionage remains an integral component of United States foreign policy as a source of information gathering from all over the world.

The existence of the espionage activity in $21^{\text {st }}$ century can be proved with many up to date cases of espionage in the world with different motives such as espionage in middle east, south asia, east asia, and russia. Espionage activities of United States in Middle East have done in some countries such as Iran, Iraq, and Libanon. The espionage in Iran, Iraq, and Libanon basically have the same motive about terorism and nuclear program. Espionage activities also happen in South Asia. United States thinks that South Asia is dangerous region where many terorist groups appear from South Asia. There are some countries as the objects of United States' espionage activity such as Pakistan and Afganistan. Countries in East Asia also to be target of United States' espionage. The motive of espionage in East Asia is different with the motive in South Asia and Middle East. The espionage motive is not about the terorism, but focus to spread of communism. North Korea and China are communist countries. United States focuses its espionage activity to both countries. Russia is old enemy of United States, so the espionage of United States to Russia is about spreading of communism ideology (Chung, 2014: 3).

From Salt films, it can be seen espionage of United States against North Korea that is more emphasis on the nuclear interests. It shows that United States is a superpower act as a world police. United States is a world police feel threatened by the existence of North Korea where North Korea has the capability to develop nuclear.

Then, in Salt films also there is espionage of Soviet Union against United States. Soviet Union's espionage againsts United States is more emphasis on the interests of Soviet Union to destroy United States that is termed as the "Day X". With the destruction of United States, then Soviet Union will appear to be a superpower in the world. Beside the motive to destroy the power of United States, espionage agent in United States has a mission to malign United States. In the end of Salt film, United States has fallen by Soviet Union's agent (Ted Winter) who is ready for a nuclear launch from United States (White House). The nuclear missiles will launch to Tehran and Mecca. Soviet Union expects all countries in the world will condemn United States for nuclear launch into the Islamic countries. Based on the explanation above, it can be 
concluded that since the Cold War era up today, there have been cases where some citizens or intelligence agents cross into other countries. They have different motives. The war of espionage is also reflected into form of film.

The film lovers surely know about Hollywood. The films that are produced in Hollywood can rule the world with all the innovation and creativity that is so alluring. Everyone knows that Hollywood is able to make the film lovers are amazed by the high level imaginations and acting of the artists that cannot be underestimated. So, the Hollywood films able to enchant the audiences around the world. There are many films that have been produced by Hollywood with a variety genres such as action, espionage-thriller, drama, horror, science and animation. The excess of the Hollywood films can be seen from their ideas that are imaginative, constructive, creative and innovative than films from another production.

One of the most preferred genre and always enter the box office is the espionage action film. It is proven by the success of many espionage films with very familiar titles such as The Bourne, Mission: Impossible, James Bond, Salt, etc. Espionage has become a very popular theme in the Hollywood film industry since the 1940s until the emergence of James Bond in the 1960s. The story of a secret agent with sophisticated weapons is wrapped in full story of intrigue into the theme that is quite interesting and able to attract the attention of the audience. Now, after the World War and the Cold War, espionage theme remain in Hollywood. Espionage films in the 2000s have been mixed with a superhero story, sophisticated technology, and supported by the sophisticated visual effects. Espionage films experience transformation from the old time to recent appearance. The transformation of the Espionage films is important to discuss by the researcher because this phenomenon will answer why the espionage still exists up to $21^{\text {st }}$ century.

History of espionage films in the late $20^{\text {th }}$ century up to $21^{\text {st }}$ century has influenced by the two developments that relate to each other. The political situation in the world and the growth of the popular mass media give influence to the development of the espionage films. The $20^{\text {th }}$ century is marked by the presence of the Cold War era. With the background of Cold War, it gives greater impact on the development of the espionage films. This era is known as the Spy Mania - an explosion in the espionage thriller, especially in the TV series and novels. Covert operations against the enemy. Through commercial film that the story has been politicized, then the film as a popular product into a weapon of confrontation between the two world systems in the Cold War era. The film takes place against a background of tension between 
United States and Soviet Union. The film that appears in the Cold War era includes the Red Dawn (1984) and The Spy Who Came In From The Cold (1963).

In the early $21^{\text {st }}$ century and after the case in September day (September 11, 2001), the story of the espionage films focuses on the "War on Terror". Dujmovic (2009: 7) states, "Intelligence professionals of the 21 st century, particularly those engaged in the counterterrorism mission, could use an inspirational icon from the world of literature to replace the outdated figure of James Bond." So, the terrorist attacks in September 11, 2001 has opened a new era of espionage films that featured the CIA against the terrorist (McCrisken, 2015: 310). The examples of espionage film about terorism are the film entitled Syriana (2005), Argo (2012), etc.

However, not all the espionage films that are produced after the Cold War era center on terrorism, but still a lot of espionage films that set up the background of conflict between America and Russia. Many Hollywood films that show about the America - Russia war, this case shows the tensions between the two countries still continue to this day. The Hollywood's espionage films production put Russia as an enemy. The following films are set in United States - Russian relation are Thirteen Days (2000), Get Smart (2008), Salt (2010), Mission: Impossible - Ghost Protocol (2011), etc.
Many espionage films with the theme of conflict between America and Russia show that the rivalry between United States and Russia is never ending. The competition is transformed into a form of war in the film that seemed eternal. Many films that tell the Russian effort against the Americans. Start of smuggling secret agent, to burn down America with nuclear. So it can be concluded that the Cold War between the superpowers is not over. Beside that, there are the latest espionage films Kingsman: The Secret Service (2015) and Spy (2015). Kingsman: The Secret Service (2015) is the genre of espionage film with a mix of action, adventure, and comedy. Those films are just for entertaining the audiences.

The films with the theme of secret and intelligent espionage have made the curiosity and appeal to the large audiences with their exotic, travelogue locales, nifty gadgets, ingenious toys to combat evildoers, fast-action suspense, genius of the story, the sophisticated technology, and the act to challenge the state authorities of make the espionage films as the high grade and get a lot of suspense. Besides, there are some cases that make the espionage films are different. There are the actionoriented, sophisticated, and skillful agent, with a taste for dry martinis, fancy clothes with tuxedo and cars, battled various types of eccentric, deadly and infamous criminals who planned to assault the world. The flashy agent bore little resemblance to the real shadowy 
world of espionage. Espionage action films that do not show more about dialogue.

Hollywood is a giant studio, the film industry's center since the end of World War I (Auge, 2002: 148). CIA supervises the activities of Hollywood and other American media will continue. The CIA has long been infiltrating agents in the film industry, press and other mass media in United States and also the countries that are considered important. This activity is in order to pave the ambitions of United States imperialism as a superpower. A way in the end of Hollywood's espionage films always show that United States' agent as the winner. Hollywood's espionage films convey the messages, values and ideas that guide the audiences in order to support United States government and CIA to save the world from the crime. The agents of CIA on their mission to save the world from crime always get the victory.

Everyone who watches the Hollywood's films knows well that Hollywood is very fascinated with espionage theme. However, the CIA's presence in a number of films already out of control since the 1970 s such as Three Days of the Condor up to The Bourne trilogy (Alford and Graham, 2008: 2 - 3). CIA not only provides and guidances to the film producer, but also offers funds to them. CIA has a special relationship with the entertainment industry, devoting a considerable attention to fostering relationship with Hollywood movers and the studio executives, producers, directors, actors. CIA also recruits actors to give more visibility to the propaganda projects abroad.

Hollywood's espionage films succeed to attract the public attention in United States because it shows the heroism of CIA's agents. So, CIA's agents in the espionage films become the icon about the power of CIA. Hollywood creates many icons of CIA's agent through espionage films that are produced. Most of espionage films that are produced by Hollywood tells the story of a CIA's agent. The espionage films and icons of the secret agents created by Hollywood are expected that the films are able to achieve a certain mission. One of the missions behind the films is to create a positive image of United States. United States is as superpower and world police. From this description, it can be concluded that Hollywood is still one of the tools of United States government agencies, including Pentagon and CIA.

The transformation of the espionage films from time to time reflects the interest of the audiences or the film lovers to the espionage films. It is a motivation for the Hollywood to continue create the newest espionage films to fulfil the market demand. It means that the espionage films are the popular film in literature and amuse the audiences.

\section{CONCLUSION}


Symbolically, Cold War is over, but practically the war is not over. The end of Cold War is not the end of popular literature that theme on Cold War. Espionage is a new form of Cold War. There are same cases of espionage such as the recruitment of espionage agent, the placement of espionage agent, the secret cover of espionage agent, the women agent in espionage, and the special devices of espionage agent. The appearances and practices of espionage between United States and Soviet Union are reflected in Salt film. In Salt film, Evelyn Salt is recruited become a Soviet Union's agent. She is a double agent who works in CIA for Soviet Union. She does secret cover with rubber mask to hide her true identity and uses some special devices in her espionage activities. This film shows that United States is the winner of Cold War with its espionage activity.

\section{ACKNOWLEDGEMENTS}

The reseacher would like to gratitude to the following persons: Mr. Marno, Mrs. Sulastri, Asep Isakandar, Ar-rafa Muhammad Ilyas, Septian Dwi Firmansyah, Mrs. Lusia $\mathrm{KDP}$, and all of the Literature lovers. You are my spirit.

\section{REFERENCES}

Adi, I. (2011). Fiksi Popular: Teori \& Metode Kajian. Yogyakarta: Pustaka Belajar.
Espionage still exists up to $21^{\text {st }}$ century because United States as the superpower tries to be a superior in the world. United States does espionage activities to the some countries in the world and have the difference motives. United States' espionage includes spy activities in Afghanistan and in Pakistan suspected as the terrorist hideout, in China and Soviet Union as countries whose the communist ideology and economy grow rapidly, in Iran and the Middle East as area with the nuclear exploration programs, and North Korea as the communist.

Espionage becomes very popular theme in the Hollywood. The transformation of the espionage films are done by Hollywood to fulfil the market demand. Beside getting income, there is a secret mission of Hollywood to show the superiority and power of America as an international police.

Alford, M. \& Graham, R. (2008). An offer they couldn't refuse. The Guardian News.

(http://www.theguardian.com/film/200 8/nov/14/thriller-ridley-scott) accessed on April 14, 2015.

Ary, D., Jacobs, C., \& Sorensen, C. (2010). Introduction to Research in Education (Eight ed.). Belmoth: WADSWORTH CENGAGE Learning.

Auge, E. (2002). Hollywood Movies: Terrorism 101. Cercles 5, p. $147-163$.

Aunesluoma, J., \& Kettunen, P. (Eds.). (2008). The Cold War and the Politics of History. Helsinki: Edita Publishing Ltd. 
Box Office Mojo. (2015). Salt (2010). (http://www.boxofficemojo.com/movies/ ?id=salt10.htm) accessed on February 23, 2015.

Chung, E. (2014). The Role of Espionage in Foreign Relations. Harvard Model Congress.

Dujmovic, N. (2009). Stephen Maturin: The Ideal Intelligence Officer for Our Times. Studies in Intelligence, Vol. 53, No. 2.
Lerner, K. L. \& Lerner, B. W. (Eds.). (2004). Encyclopedia of espionage, intelligence, and security. USA: Gale Group, Inc.

McCrisken, T. (2015). The Housewife, the Vigilance and the Cigarette - Smoking Man: The CIA and Television, 1975 2001. The Journal of the Historical Association.

Strinati, Dominic. (1995). An Introduction to the Theories of Popular Culture (Second $E d)$. London: Roudledge. 